ljtihad: Jurnal Wacana Hukum Islam dan Kemanusiaan

Vol. 18, No. 2 (2018), pp. 137-152, doi : 10.18326/ijtihad.v18i2.137-152

\title{
Developing BMT as a loss-profit sharing-based microfinance: an Indonesian experience
}

\author{
Husni Mubarrak \\ Universitas Islam Negeri (UIN) Ar-Raniry Banda Aceh \\ E-mail: husnilatief@yahoo.com \\ DOI: 10.18326/ijtihad.v18i2.137-152
}

This article would like to discuss an Indonesian experience in developing Baitul Mal wat Tamwil (BMT) since 1990's as an alternative microfinance which based on loss and profit sharing schema that realized a more just economic system. This research is conducted by both bibliographical overviews and empirical investigations. This paper would like to elaborate more on how BMT developed and maintained its capacity and efforts, in providing a more just alternative model instead of interest system which had shown negative spread and pseudo economic growth. This, however, requires emphasizing the main differences between both systems (sharing and interest). It also discusses on how BMT upgraded competitively various attractive products which based on loss and profit sharing. The establishment of BMT in Indonesia could not be separated from the emergence of "creative minority" and "enlightened group" in some campuses in Indonesia to build BMT since 1984, which later followed and developed by Indonesian Muslim Intellectual Association (Ikatan Cendekiawan Muslim Indonesia/ ICMI) since 1991. The research findings showed that the schema which is used by BMT on loss and profit sharing is a real practical effort which then has successfully developed, massively contributed and largely triggered Indonesian economic in the real sector, especially for the small and medium economic scale enterprises (SMES) in order to poverty alleviation. It also reflected as an experiment of early steps in recognizing Islamic economy in Indonesia. BMT also still could survive, even when a huge economic crisis struck Indonesia particularly and South East Asia generally in 1997.

Artikel ini ingin membahas pengalaman Indonesia dalam mengembangkan Baitul Mal wat Tamwil (BMT) sejak tahun 1990-an sebagai alternatif keuangan mikro yang didasarkan pada skema pembagian untung dan bagi hasil yang mewujudkan sistem ekonomi yang lebih berkeadilan. Penelitian ini dilakukan melalui studi bibliografi dan investigasi empiris. Artikel ini menguraikan lebih lanjut tentang bagaimana 
BMT mengembangkan dan mempertahankan kapasitas dan upayanya, dalam menyediakan model alternatif yang lebih adil daripada sistem bunga yang telah menunjukkan dampak penyebaran negatif dan pertumbuhan ekonomi semu. Hal ini, bagaimanapun, membutuhkan menekankan perbedaan utama antara kedua sistem (antara bagi hasil dan bunga). Artikel ini juga membahas tentang bagaimana BMT meningkatkan secara kompetitif berbagai produk menarik yang didasarkan pada kerugian dan pembagian keuntungan. Pembentukan BMT di Indonesia tidak dapat dipisahkan dari munculnya "minoritas kreatif" dan "kelompok tercerahkan" di beberapa kampus di Indonesia untuk membangun BMT sejak 1984, yang kemudian diikuti dan dikembangkan oleh Asosiasi Muslim Indonesia (Ikatan Cendekiawan Muslim Indonesia / ICMI) sejak tahun 1991. Temuan penelitian menunjukkan bahwa skema yang digunakan oleh BMT tentang kerugian dan bagi hasil adalah upaya nyata yang kemudian telah berhasil dikembangkan, berkontribusi dan memicu ekonomi Indonesia di sektor riil, terutama untuk sektor kecil dan usaha skala menengah (UKM) dalam rangka pengentasan kemiskinan. Ini sekaligus juga mencerminkan percobaan langkah awal dalam mengenalkan ekonomi Islam di Indonesia. BMT juga masih bisa bertahan, bahkan ketika krisis ekonomi besar melanda Indonesia khususnya, dan Asia Tenggara umumnya, pada tahun 1997.

\section{Keywords: Loss-Profit Sharing; Baitul Mal wat Tamwil; Microfinance; Poverty Alleviation}

\section{Introduction}

Among the most challenges to realize social welfare of humankind in this modern era is inequality of chance and opportunity to access financial services, particularly for the poor people. Many reasons could be proposed in explaining such phenomenon; either from reality side of wealth accumulation that still circulating in the hands of few, or the existing conventional economic system itself, obstructs the needy and the poor people, even weakens them to be excluded from financial services, and then trapped in the vicious cycle of poverty. However, the access of the poor unease in the financial system are the main factors that play a role in the inability of community in the development process (Lasmiatun, 2014).

Although both above reasons are seemly different, but in reality, they are interrelated to each other. The later is supporting the former. The current existing conventional economic system of the world acknowledges and imposes the interest which arguably as the importance means and the main factors of economic growth, reinforces the tendency for wealth to accumulate in the hands of few (the rich). Actually, interest reflects psendo growth of economy and exploitation, as well, by consuming other's wealth unlawfully which then makes the poor becomes poorer and the weak to be weaker. 
Turning from this perspective, it becomes important to think an appropriate tool and system in order to help and empower economic of the poor, by providing enough and easy financial service for them. Moreover, it should also be objected to develop a more just economic system. Many efforts in various ways have been exerted to develop such economic empowerment, what later known as the microfinance. This financing is an attempt which is designed specifically to meet particular needs and circumstances of the needy and the poor, simply understood, locally provided and quickly accessible. It is believed that through access to small financing creates a virtuous cycle of investment and increased income, as well (Khan, 2008: 6).

In terms of developing microfinance, as the biggest country of Muslim population in the world, Indonesia has broadly experienced, applied and practiced Baitul Mal wat Tamwil since 1984. From the beginning of its foundation, BMT which emerged from some campuses in Indonesia, is aimed to economic development for small and medium enterprises (SMES) by providing access to financial service. Additionally, BMT also has applied loss and profit sharing for its operational mechanism. It is interesting to elaborate more on how BMT developed and maintained its capacity and efforts, in providing a more just alternative model instead of interest system. To give a comprehensive understanding, it is important to be noted here that BMT has also upgraded competitively various attracted products which based on loss and profit sharing. So that, it becomes necessary to be mentioned here, what is the unique of loss and profit sharing that distinctly differs it from interest one by emphasizing the main differences between both systems (loss-profit sharing and interest).

To this end, the second section will provide a brief history of the emergence of BMT in Indonesia, including idea, spirit and power. The third section will explain the concept and practice of BMT in Indonesia, while the fourth section will discuss on loss and profit sharing mechanism that adopted by BMT, continued by fifth section about chance and challenge on developing BMT as an Islamic microfinance, and the last will be closed by conclusion.

\section{The emergence of BMT in Indonesia: idea, spirit and power}

Concerning that the limited access and canal of financial service is the main problem for economic empowerment-especially for the needy and the poor-beside unjust existing 
ljtihad: Jurnal Wacana Hukum Islam dan Kemanusiaan, Volume 18, No. 2, Desember 2018: 137-152

economic system by prevailing interest for loan transaction, this unfavorable situation has strongly stimulated and urged well educated people in Indonesia since 1980s to think and develop a more just alternative system, strongly rooted to Islamic values, that prohibits interest (riba), uncertainty (gharar), and gambling (maysir).

However, today interest is well-known to all people and has become so institutionalized and accepted in modern economies that is almost impossible to conceive that an economy can run without interest. All people including the Muslim society within are now constantly being forced with fragile arguments in support of dealing with interest which eventually lead them to accept the concept of interest.

Witnessing this reality, has triggered some Muslim intellectuals and academicians in Indonesia to seek an alternative way and attempt to build a just economic system in order to resist the mainstream economic canal with interest as the prime. Serious exerts should be cultivated, even in a small scale which aimed to eliminate interest from economic activities. This attempt was begun by the appearance of "creative minority" and "enlightened group" in some campuses in Indonesia has established Baitul Mal wat Tamwil (BMT) in 1984 which later followed and developed by Indonesian Muslim Intellectual Association (Ikatan Cendekiawan Muslim Indonesia/ ICMI) since 1991 (Widiyanto, Ismail, Kartiko, 2016).

At the beginning of 1995, the Chair of Indonesian Muslim Intellectual Association/ ICMI (Ikatan Cendekiawan Muslim Indonesia) made collaboration with the Chair of Indonesian Ulama Assembly/MUI (Majelis Ulama Indonesia) to build a foundation named Yayasan Inkubasi Bisnis dan Usaha Kecil (YINBUK), a foundation for developing micro entrepreneur, legalized in front of a notarist Leily Yudoparipurno, SH. No. 05, March, 13, 1995 (Harahap and Basri, 2004). The objective of this foundation is to develop micro and medium entrepreneur. The operation of YINBUK is supported by Pusat Inkubasi Bisnis dan Usaha Kecil (PINBUK), a center established by YINBUK for developing micro entrepeneur in the society. This foundation, by the time, also actively contributed to the development of BMT as an Islamic microfinance institution spreading overall Indonesia.

BMT is an Islamic microfinance institution in Indonesia that has integrated all economic and social activities to the rural society. BMT consists of Baitul Mal and Baitut Tamwil. The activity of BMT as baitut tamwil is to develop productive business by promoting saving activity 
and helping the members by providing many financing scheme to many business activities based on shariah principle and cooperation which based on loss and profit sharing. BMT as baitul mal has also social function by supporting social fund such as zakat (Islamic alms), infaq (donation), shadaqah (charity) to be distributed with the principle of society empowerment to those who are deserve it (mustahiq). So, it can concluded that BMT operation is based on shariah principle.

Since its beginning foundation, BMT has been purposed to empower and enhance economic of small and medium scale enterprises (SMES) in order to poverty alleviation by applying loss and profit sharing as financing-based mechanism. The emergence of BMT could also not be separated from the spirit to eliminate usury (riba) from Moslem economic activities in their daily life in Indonesia. In addition, BMT has largely tried to apply Islamic finance contracts in appropriate to Islamic sharia based product, either in finance (such as musyarakah, mudharabah) or trade (murabahah).

BMT has more outreach rather than Islamic Banking. The outreach of Islamic Banking is usually in the big cities or capital cities. Meanwhile BMT has their outlet and office in small rural cities, village, suburbs or big cities' slum. Currently, there are more than 5000 BMT has established in many regions in Indonesia that provide micro finance services. Besides its role as a financial institution that mostly profit taking orientation, BMT has its social role, as well, by providing an equal access to financial services especially for the needy and the poor in the villages and rural areas. So that as an Islamic micro finance, BMT does only not focus on financial collecting from the customers through saving sharia based product, like wadi'ah and mudharabah, but also provide financial distributing through some Islamic finance contracts which loss-profit sharing based.

Additionally, to support its social benefit, BMT also initiate to provide a portion of benevolent loans by asking the borrower should only repay the principal. This kind of contract is well known as al-qardhul hasan (as mentioned in Al-Qur'an) which strongly recommended in Islam to be done among Muslim in order to help the needy. Dealing with this, a study done by Farook (2007) quietly insists that Islamic micro finance should implement al-qardhul hasan among its financial products as a form of social responsibility of Islamic financial institution in fulfilling social welfare for the poor and the needy. 
In this light, BMT has largely contributed of introducing and implementing the values of Islamic economy in Indonesia since the beginning. Those values are reflected in providing a more just model transaction and also avoiding the unlawful due in Islam, such as preserving the principle of "'an taradhin minkum" (mutual willingness between both parties) as well as the principle "la tazhlimuna wa la tuzhlamun" which means "inflict no evil, and not be inflicted by it" whereas prohibition of interest or usury (riba) is one of them.

\section{The concept and practice of BMT in Indonesia}

In very simply, the concept of BMT based on canalizing of Islamic financing transactions and Islamic model through its various products (Baitut Tamwi), besides providing social mission, and recognizing the Islamic teaching through its services for the needy and the poor (Baitul Mal). By both roles (mal and tamwil) that functioned by BMT, it shows a very distinctive point of BMT from any other micro finances, that in its capacity as an Islamic micro finance, BMT is not only in line with Islamic teachings and Islamic values, but also being as a medium of Islamic da'wah. It can be noted here that BMT has commercial function to gain profit, and has social responsibility to help the needy as well as spiritual spirit to implement financial transactions in line with Islamic values (Widiyanto, Ismail, Kartiko, 2016: 20).

As a viable financial institution, BMT is offering products and services similar to the Islamic banks and shariah rural banks (BPRS/Bank Perkreditan Rakyat Syariah). However, it has a different market sector in terms of patronage, where the Islamic banks mainly cater for the middle class and the white collar Muslims. BPRS on the other hand mainly provides services for Muslims from the middle and the lower income groups. While BMT usually serves the Muslim customers who run small and medium enterprises and whose access to the banks is relatively limited, some customer overlapping occurs among the Islamic bank, BPRS and BMT (Sakai and Marijan, 2008).

Regarding financing (tamwi), BMT has made any efforts to apply Islamic finance contracts which in appropriate to Islamic sharia based product, either in finance (such as musyarakah, mudharabah) or trade (murabahah). The contract of murabahah which known as "sale and purchase contract that mutually agreed profit margin" or more known as "mark-up purchasing" is still being preferred and prioritized to be implemented by BMT. 
One of the reasons, because murabahah has the fix return, until it seemingly supposed to be closer to the banking interest rate practice. In fact, both are unequal, as Usmani (2002) mentioned that murabahah is the first step of Islamization economy process that can also be a solution to prevent spread out of interest transaction as it works in conventional institution. The ideal financing that reflects Islamic justice is still mudharabah and musyarakah (equity participation contract), because both are based on loss and profit sharing schema.

Meanwhile due to its function as baitul mal, BMT plays an important role in terms of improving quality of life for the needy and the poor by collecting zakat, infaq and shadaqah (Islamic alms and charity) and then distributing it for them, either through direct transfer payment or al-qardhul hasan financing. By al-qardhul hasan, it is hoped that it can contribute in favoring the needy, besides triggering their economic through multiplier effect.

In short, it can be concluded that the existence of BMT has two interrelated functions regarding poverty alleviation. The first, BMT focuses on financing contracts with Islamic sharia based products, by applying loss and profit sharing schema as a more just and serious attempt to eliminate interest from economic activities, especially regarding saving and loan. The practice of interest has really exploited and caused the poor become poorer, and the weak to be weaker, so that it is really an unjust transaction. The second, BMT is actively collecting and distributing portions of zakat, shadaqah and other modes of charity that effectively empowering the economic activities of the needy and the poor trough direct transfer payment, as a form of social responsibility. BMT is also providing a portion of benevolent loans through al-qardhul hasan financing which perceived as potential to be developed further as a poverty alleviation model (Widiyanto, Mutamimah, Hendar, 2011).

To sum up, according to Yumna and Clarke (2012), the main features of BMT are:

1) Providing adequate services for the extremely poor clients and lift some of them to the economically active poor clients.

2) It is possible to create a sustainable microfinance since it does not only depend on the donor fund to provide the microfinance.

3) It increases the accountability of the both institutions since they need to report to zakat and Islamic charities payers and its potential payers, shari'ah compliance finance as well as the microfinance institution supervisory board. 
4) It will create sustainable microfinance with lower default rate and reduce the possibility of misuse of the loans since the microcredit is only for the skilled people who conduct some income generating activities.

5) It will reduce the agency problems since both institution engage in the same value and objectives.

\section{What unique of loss and profit sharing schema?}

To understand what interest means in a very simple way-as it is known in the current economic practice-interest is commonly prevailed in loan and credit transactions. Interest is a kind of fee charged by a lender to a borrower for the use of borrowed money, usually expressed as an annual percentage. Interest also understood as the excess of money paid by the borrower to the lender over and above the principle for the use of liquid money over a certain period of time. So that, interest mostly becomes a tool of economic exploitation to the others and a kind of consuming other's wealth unlawfully which makes the poor becomes poorer and the weak to be weaker. Hence, the interest is prohibited not only in terms of religious order, but also by the early scholars like the Greek philosophers who took a very negative way of interest, because it is unjust and contrast to human nature of man (Hossain, 2009).

Actually, there is a stronger term which appropriately used to describe this unlawful deed; it is the term "usury" which is prohibited in all religions, from Jew, Christian and Islam. By time, the term "interest" which basically means smoother, is preferred to be circled and used, instead of "usury". The term "usury" is very close meaning to the word "riba" in Al-Qur'an, which has four passages found in four different surahs in which interest is condemned or prohibited, even stated as a very serious sin. These passages, in probable chronological order in Al-Qur'an, are: (30:39), (4:161), (3:130), (2:275-280). When one reads the Islamic texts concerning interest, one is immediately taken by how stringent the warnings are against any involvement in interest, even it seems no other issue has been condemned and denounced so strongly in the Al-Quran as has usury (riba) so that it is prohibited and should be eliminated (Al-Sha'rawiy, 2007: 15-18).

This prohibition extends to any and all forms of interest. It could be concluded that all kinds of interest are riba (usury). And it is argued that riba is a sin in Islam, and even those 
hired to write the contract or who witness and thus confirm the contract are party to the sin. Al-Qur'an very clearly states that riba leads to destruction and shadaqah (charity) to growth. According to Raquib (2007), the elimination of riba within economic system is purposed in order to promote a more just economic system, a more just social relationship as well as ethical values in line with Islamic order and teaching.

Similarly, Siddiqi (1981) mentioned in very clear the main reasons why among Islamic teachings orientation basically is purposed to eliminate interest within humankind's economic transactions. Because interest is a type of increase in a loan so that taking interest is zulm (injustice) and a kind of exploitations. Commonly, interest often involved doubling and redoubling of the debt, so it can be inferred that dealing in interest is gaining through the wealth of other people. The interest reinforces the tendency for wealth to accumulate in the hands of few which is strictly forbidden in Islam, which absolutely will restrict realization of social equilibrium. In other word, interest means a form of the wealth transfer from the poor to the rich to become a richer.

The absolute prohibition of interest in the Qur'an is also a command to establish an economic system, from which all forms of exploitation are eliminated, in particular, the injustice of the financier being assured of a positive return without doing any work or sharing in the risk, while the entrepreneur, in spite of management and hard work, not being assured of a positive return. The prohibition of interest is therefore a way to establish justice between the financier and the entrepreneur (Khan, 2008: 11).

It becomes arguably then, why a more just economic framework which provides legal and fair transaction activities is needed and should be presented and performed in order to eliminate all kinds of injustice and authoritarian whereas interest among them. From this, the appearance of Islamic finance as the solution meets its significance in providing a more just and equal economic system.

As Abdullah (2010) mentioned that key principles of Islamic finance is should be built and based on five pillars, i.e: (i) belief in Divine guidance through Al-Qur'an and Sunnah, (ii) no interest transactions, (iii) no harm (forbidden) or sinful investment, (iv) risk sharing is encouraged, and (v) financing is based on real asset. 
In similar, Khan (2008: 9-16) cited that the unique of Islamic finance because it should be established on some principles and pillars, i.e. the prohibition of the interest as the main focus; and also encouraging to use and seize some models of Islamic finance mechanisms and contracts such as murabahah, mudharabah, musyarakah, ijarah and qardhul hasan. Even, mudharabah and al-qardhul hasan really reflect the Islamic ideal financing which describe justice and equality because both are based on loss and profit sharing (i.e. mudharabah) and a form of benevolent loan (i.e. al-qardhul hasan) by asking the borrower should only repay the principal. Both contracts are in line with the main spirit and message of Islam to help one another unto righteousness and pious duty.

In terms of the principle of loss and profit sharing, the reason why it is more appropriate to be applied in Islamic finance transactions, could be not separated from the perspective that Islam itself does not allow gain a fix return without any risk sharing, unless the financial capital is also exposed to the risk of potential loss. Because it is conceived, the money is not an earning asset in and of itself. Equally to this, the financing transaction in Islam requires appropriateness of sharia compliant, including there must be some risk, whether funds are used in a commercial or productive venture. In Islamic sharia finance, there are well known rules, al-ghunmu bil ghurmi (business profit goes along with business risk) and al-kharaj bi aldhaman (business proceed goes along with capital) or in another term, it is equal to high risk, high return; low risk low return (Al-Sya'rawiy, 2007: 34-35).

Based on idea of loss and profit sharing, if an individual wishes to use his money to make more money, then he must be willing to put his money at risk. If he puts his money at risk, he can deserve some share of the profits. This implies that he must accept losses if losses occur. This is a system that is based on justice.

On the contrary, interest is forbidden because it is a predetermined, fixed sum owed to the lender, irrespective of the outcome of the business venture in which the fund is used. This does not imply in any way that capital is free of charge, or that should be made available without any cost, or that there should be absolutely no return on capital. Rather, a return on capital is allowed, as long as the capital participates in the productive process and is exposed to business risk. 


\section{Developing BMT as an Islamic microfinance: chance and challenge}

As indicated by Rusyana (2014) that what is remarkable about BMT's is that their development has been supported largely by individuals and private organizations rather than the government. Interestingly, they did not care about BMT legalisation status or government support. Their goals to strengthen Muslims economy, alleviate the poverty and sava them from usurer (lintah darat) motivated Muslims society to establish BMT. From here, the establishing and developing of BMT then can be categorized as an instrumental movement to achieve its goals. However, the inisiator and management of BMT should maintain and develop some great programs to alleviate poverty and to strengthen the small enterpreneur or poor people.

Rusyana (2014) also insisted and suggested that to maintain its development and movement, BMT must urgently need a system of prudential regulation, mandatory auditing and effective supervision by an appropriate financial authority (perhaps delegated to an autonomous auditing federation, but definitely not in the hands of a ministry). Thus, the government should take a role to support and strengthen BMT. In other hand, the associations of BMT, such as PINBUK, may be strengthened to eventually replace a governmental agency like the Ministry of Cooperatives, which, in the framework of massive government interference under the previous political system, seems to have had a more detrimental than constructive effect in terms of building self-reliant, healthy cooperatives.

Turning from spirit against the interest from any financial transactions done by BMT, it has simultaneously applied and implemented loss and profit sharing schema through various products in servicing the customers. The products are vary, including sale and purchase transactions such as murabahah, istishna and salam; loss-profit sharing transactions like mudharabah and musyarakah; or any other transactions such as ijarah, qardh and rahn. BMT has also broadly provided loans for the poor and the needy for investments in productive activities through al-qardhul hasan in order to increase their income. Although it cannot eliminate poverty as a whole, but such noble attempt quite be appreciated to be a powerful tool in the battle against poverty.

Some studies done researching on development of BMT are supporting above statement. As shown by studies conducted by Ronald (2013), Adlin Sila (2010) and Widiyanto (2007), that BMT in its $3^{\text {rd }}$ decade of existence has successfully developed, massively contributed 
and largely triggered Indonesian economic in the real sector, especially for the small and medium economic scale enterprises (SMES). Even BMT also still could survive, even when a huge economic crisis struck Indonesia particularly and South East Asia generally in 1997. Among the reasons is because BMT was managing small financing with low risk in the real sector, so it can still survive whereas many interest based financial institutions collapsed at that time. In addition, a study done by Widiyanto et.al (2011) showed that an effective al-qardhul hasan financing which is accompanied by Islamic values and spirituality supervision during the financing period, has effectively increased income of the needy as well as formatting personality of the borrower to be more honest, discipline and independently in debt payment. It can be inferred shortly, that BMT has big opportunity to be flourish able in the future and furthermore to be as an ideal Islamic microfinance in Indonesia.

Beyond all of those achievements, BMT is undeniably facing various challenges that can restrict its performance. As stated by Zouari \& Nabi (2013: 2) that Islamic micro finance has great potential to contribute to alleviating poverty and enhancing development, but it also faces a lot of challenges, all together. Among the challenges is how to train staff be more capable to master Islamic finance concepts and products which can help them in giving understanding of Islamic financing to the customers, because BMT is not only commercial profit orientation, but also has social benefit role by economic empowering or enhancing role as well as educating people.

Another challenge is, in this globalization era, as an Islamic micro finance, BMT is demanded to continuously enhance the capacity and ability in order to be better in providing financial services. Beside form and type of other microfinance are vary, they are very competitive, too. So that the real challenge for the existence of BMT is how to be a sportive competitor which still commit with Islamic values and teaching simultaneously during the operation whereas other general micro finance have no such religious spirit.

Regarding Indonesian context, the presence of more conventional micro finance with providing soft loans of lower interest rate for the small business enterprises is a really challenge for BMT. To mention some of those conventional micro finances are the appearance of Financial Inclusion which aimed to reach unbanked people that is going to be national agenda to tackle poverty issue in Indonesia. Actually, the presence of Financial 
Inclusion is not a new issue regarding such attempt has been applied before, through micro finance and other financial institutions. But the challenge is, recently, it has appeared a movement "Alliance Financial Inclusion" (AFI) as a global movement, funded by Bill Gate Foundation and World Bank in terms of supplying financial services for developing country which Indonesia inside. The challenge is AFI has its own hidden agenda to build global network towards liberalism of micro finance with value-free based, or materialism oriented. Additionally, loan that supplied by AFI is mostly purposed to consumptive use, not productive. This vision and model of AFI is really opposite to the existence of BMT which aims to Muslim and Ummah economic empowerment with Islamic value-based (Widiyanto, Ismail, Kartiko, 2016: 121-125).

In this regard, it really challenges BMT to sustainably enhance and supervise its capacity and ability in order to be better in providing financial services in line with Islamic values and teaching with no interest and harm (forbidding) transactions.

However, the existence of BMT is rapidly increasing. As noted by Lasmiatun (2014), the form of Baitul Mal wat Tamwil (BMT) has good prospects to be developed in Indonesia given the potential possessed by this country. It has two functions, namely as a function of social and business functions. Development of BMT must be supported by the government that became increasingly powerful role in society, and can help governments improve the welfare of society equally (Lasmiatun, 2014).

The existence of BMT now also faces many various challenges and problems. Among the challenges of BMT in the current time could be summarized as follow (Kholis, 2012):

1) Regulations and standardization for BMT establishment and operation;

2) Human resources who operate BMT;

3) The cost of fund which is still higher and more expensive rather than conventional one;

4) Public perception on interest;

5) Limitation on the service based on IT (information technology).

In addition, Rusydiana and Devi (2013) based on their study also stated that the main problems which could be the challenge for BMT in the future can be divided into four aspects, namely: Human Resources; Technical; Legal and Structural, and Market/Communal. 
ljtihad: Jurnal Wacana Hukum Islam dan Kemanusiaan, Volume 18, No. 2, Desember 2018: 137-152

\section{Conclusion}

I began this paper by the statement that among the most challenges to realize social welfare of humankind in this modern era is inequality of chance and opportunity to access financial services, particularly for the poor people. The causes are vary; either from reality side of wealth accumulation that still circulating in the hands of few, or the existing economic system itself, obstructs the needy and the poor people, even weakens them to be excluded from financial services, and then trapped in the vicious cycle of poverty.

In spite of both reasons are seemly different, but in reality, they are interrelated to each other. The later is supporting the former. The current existing conventional economic system of the world acknowledges and imposes the interest, has reinforced the tendency for wealth to accumulate in the hands of few (the rich). Beside, interest reflects psendo growth of economy and exploitation, as well, by consuming other's wealth unlawfully which then makes the poor becomes poorer and the weak to be weaker.

A further study conducted by Ahmed (2002) indicated that there are many facts point out the failure of the conventional microfinance which could be concluded as follow: (1) asymmetric information problem; (2) economic viability of the conventional microfinance institution; (3) Low rate return on investment; (4) high drop out rate and non-graduation from poverty; (5) debt trap; and last but not the least, (6) targetting women as recipient.

In this regard, as the biggest country of Muslim population in the world, Indonesia has long experience in developing Baitul Mal wat Tamwil (BMT) since 1984 as an alternative microfinance which based on loss and profit sharing schema that realized a more just economic system. This financing is an attempt which is designed specifically to meet particular needs and circumstances of the needy and the poor, simply understood, locally provided and quickly accessible. It is believed that through access to small financing creates a virtuous cycle of investment and increased income of the poor and the needy.

Equally important to be added here as the conclusion, that BMT seems furthermore proper to be modeled as an ideal Islamic microfinance based on its experience since 3 decades ago. The schema which is used by BMT on loss and profit sharing is a real practical effort which then has successfully developed, massively contributed and largely triggered Indonesian economic in the real sector, especially for the small and medium economic scale 
Developing BMT as a loss-profit sharing-based microfinance: an Indonesian experience (Husni Mubarrak)

enterprises (SMES) in order to poverty alleviation. BMT also still could survive, even when a huge economic crisis struck Indonesia particularly and South East Asia generally in 1997.

\section{Bibliography}

Abdullah, D. V \& Keon Chee. Islamic Finance Why It Makes Sense. Singapore: Marshall Cavendish Business, 2010.

Adlin Sila, Muhammad. "Lembaga Keuangan Mikro dan Pengentasan Kemiskinan: Kasus Lumbung Pitih Nagari di Padang" (Micro Finance and Poverty Alleviation: The Case of Lumbung Pitih Nagari in Padang, Indonesia). Jurnal Sosiologi Masyarakat. Vol. 15 No. 1(2010): p. 1-19.

Al-Sha'rawiy, 'Ayid Fadhl. Al-Masharif al-Islamiyyah Dirasat Tlmiyyah Fiqhiyyah lil Mumarasat al-'Amaliyyah (Islamic Banking a Scientific Islamic Law Study on Its Operational Practice). Beirut: Dar el-Basyair el-Islamiyyah, 2007.

Azwar Karim, Adiwarman. Islamic Banking Fiqh and Financial Analysis. Jakarta: PT. Raja Grafindo Persada. $3^{\text {rd }}$ Edition, 2005.

Farook, Said. “On Corporate Social Responsibility of Islamic Financial Instituions”. Islamic Economic Studies. Vol. 15 No. 1 (2007): p. 31-46.

Hossain, Mohammad Zakir. "Why Is Interest Prohibited in Islam? A Statistical Justification". Humanomics. Vol. 25 No. 4 (2009): p. 241-253.

Khan, A.A. Islamic Microfinance Theory, Policy and Practice. Birmingham: Islamic Relief Worldwide, 2008.

Raquib, Abdur. Principle \& Practice of Islamic Banking. Dhaka: Panam Press Ltd., 2007.

Ronald. The Role of Islamic Microfinance. Unpublished Dissertation. IIUM Malaysia, 2013.

Siddiqi, M.N. "Muslim Economic Thinking: A Survey of Contemporary Literature" in Studies in Islamic Economics, ed. K. Ahmad. pp. 191-269. United Kingdom: The Islamic Foundation, 1981.

Usmani, M.T. An Introduction to Islamic Finance. Karachi: Maktaba Ma'ariful Qur'an, 2002.

Widiyanto, Ismail, Abdul Ghafar., Kartiko. BMT Praktik dan Kasus. Jakarta: PT. Raja Grafindo Persada. $1^{\text {st }}$ Edition, 2016.

Widiyanto, Mutamimah, Hendar. "Effectiveness of Qard Al-Hasan Financing as a Poverty Allevation Model". Economic Journal of Emerging Markets. Vol 3 Issue 1(2011): p. 27-42

Widiyanto. Effectiveness and Sustainability of Baitul Mal Wat Tamwil Financing in the Development of Micro-Enterprises in Central Java, Indonesia. Doctoral Thesis: University Putra Malaysia, 2007. 
ljtihad: Jurnal Wacana Hukum Islam dan Kemanusiaan, Volume 18, No. 2, Desember 2018: 137-152

Zouari, Zeineb. \& Nabi, Mahmoud Sami. "Enhancing the Enforceability of Islamic Micro FinanceContracts in OIC Countries". IRTI Policy Paper. Jeddah: Islamic Research and Training Institute, 2013. 